\title{
PERFORMANCE OF GRAPPLE SKIDDER IN DIFFERENT GROUND INCLINATIONS
}

Carlos Cézar Cavassin Diniz ${ }^{*}$, Nelson Yoshihiro Nakajima², Renato Cesar Gonçalves Robert ${ }^{3}$, Cícero Jorge Fonseca Dolácio $^{4}$, Franciele Alba da Silva ${ }^{5}$, Daniel Francisco Balensiefer ${ }^{6}$

\author{
1Universidade Federal do Paraná, UFPR, Programa de Pós-Graduação em Engenharia Florestal, Curitiba, Paraná, Brasil - \\ carlos.diniz@ufpr.br; nelson.nakajima@ufpr.br; renatorobert@hotmail.com; cicerodolacio@ufpr.br; francielealba47@gmail.com; \\ danielbalensiefer9@gmail.com
}

Received for publication: 09/10/2017 - Accepted for publication: 25/05/2018

\begin{abstract}
Land slope contributes to decrease the productivity in the forestry sector activities, including skidding operations. Thus, it is important to study it in order to improve the forest operations planning. Based on this hypothesis, this study aims to analyze the times of the operational cycle and the productivity of the skidder in slope terrain. The study was conducted in Pinus taeda plantations of a forest company located in the CentralWest region of the state of Paraná, Brazil, in three slope classes: flat to moderate, steep and very steep. The data were obtained by the continuous timing method in a time study. Productivity and mean effective cycle time were determined for the three slope classes. The results show that the search and load and the unloading slopes are the ones that consume less time between the activities evaluated in the operational cycle. Considering the slope classes evaluated, flat to moderate and steep require less time to perform all activities of the operational cycle, and their productivities are higher, when compared to the very steep slope class. The productivity of the very steep slope class was $35.3 \%$ and $45.0 \%$ lower than the flat to moderate and steep classes, respectively. Skidding with skidder on slopes over $26.1^{\circ}$ should be avoided because the productivity is negatively influenced in this condition.

Keywords: Skidding, planning, productivity, slope.
\end{abstract}

\section{Resumo}

Desempenho do skidder de garra em diferentes declividades do terreno. A inclinação do terreno contribui para a redução da produtividade em atividades do setor florestal, inclusive na extração madeireira com skidder. Sendo assim, é importante estudá-la para que as operações florestais sejam melhor planejadas. A partir dessa hipótese, este trabalho teve como objetivo analisar os tempos do ciclo operacional e a produtividade do trator florestal skidder na extração de madeira em terrenos inclinados. O estudo foi conduzido em plantios de Pinus taeda de uma empresa florestal localizada na região Centro-Oeste do Paraná, Brasil, em três classes de inclinação: plana a moderada, íngreme e muito íngreme. Os dados foram obtidos pelo método de cronometragem contínua em um estudo de tempos e movimentos. A produtividade e o tempo efetivo médio do ciclo foram determinados para as três classes de inclinação. Os resultados demonstram que a busca e carga e o descarregamento são as que consomem menos tempo entre as atividades avaliadas do ciclo operacional. Considerando-se as classes de inclinação avaliadas, a plana a moderada e a íngreme precisam de menos tempo para a realização de todas as atividades do ciclo operacional, e suas produtividades são superiores quando comparadas à classe de inclinação muito íngreme. A produtividade da classe de inclinação muito íngreme foi $35,3 \%$ e $45,0 \%$ inferior às das classes plana a moderada e íngreme, respectivamente. A extração madeireira com skidder em terrenos com inclinação a partir de $26,1^{\circ}$ deve ser evitada, pois a produtividade é influenciada negativamente nessa condição.

Palavras-chave: Arraste, planejamento, produtividade, relevo.

\section{INTRODUCTION}

With the opening of the Brazilian market for importation, at the beginning of the 1990 decade, it was possible to acquire sophisticated equipment and of high technology, when comparing to the machines used until then by companies of forest base. The mechanization of the activity of forest harvest passes then for moments of great innovations and technological advances, when the assembly plants seek to ally technology, precision and robustness in its machines. However, the sector needs trustworthy data for the choice of the system and the machine adjusted for each type of operation (NASCIMENTO et al., 2011).

The harvest of wood, along with the carriage, has great importance in economic terms within the wood production chain, representing around 50\% or more of the final cost of the product ranked in industry (MACHADO, 2014). According to Machado et al. (2008), the harvesting activity includes cutting down of trees, processing and extraction of wood. Arce et al. (2004) states that forest harvesting represents the final operation of forest production cycle, in which the most valuable products are obtained, constituting one of the factors that determine the forest profitability.

FLORESTA, Curitiba, PR, v. 49, n. 1, p. 041-048, jan/mar. 2019

Diniz. C.C.C. et.al.

ISSN eletrônico 1982-4688

DOI: $10.5380 /$ rf.v49i1.55744 
In addition, the harvest is influenced by several factors that interfere directly in the productivity and costs of production, such as slope, average individual volume, density, among others (MACHADO; LOPES, 2000). To Fiedler et al. (2017), forest harvesting activity must be planned aiming at the logistics of machine and cutting optimization and seeking lower costs with the activity, as well as increasing the productivity of wood harvest system. In this context, it is necessary to improve techniques within the harvesting of wood, in order to increase productivity and reduce production costs and seek to combine improvement of work quality and reduction of impacts to the environment.

The extraction is one of the most complex stages of wood harvesting, since the cost of this step is influenced by several factors, such as the level of experience and skill of the operator, the settlement conditions, characteristics of the terrain, distance from extraction, machine performance, among others (LOPES et al., 2007).

Lopes and Diniz (2015), studying the productivity of the forest tractor chocker skidder in the wooden extraction in inclined lands, concluded that the increase of extraction distance and land inclination contributed to a productivity reduction of cable skidder. Such variable must be considered in the planning of the forest operations in inclined lands. Parker et al. (2015) also noted, with regard to the productivity of the skidder, that the increase in the total volume of the population showed the highest influence on smaller distances of extraction and harvesting of wood in different population productivity. The estimates of productivity and cost based in the data supplied for manufacturers or obtained in works carried through in other countries reveal itself as sufficiently fragile, indicating, therefore, the necessity of producing studies for each specific condition (PEREIRA et al., 2015).

Lopes et al. (2015) comment that in the last years, in the market of extraction in places with inclined terrain, alternatives were appointed such as machines like the forwarder, equipped with auxiliary traction winch, and the skidder, equipped with the option of use of auxiliary cable for the screwing of the trees. From this, the correct choice of machinery and their implements interfere in logging operations in different operating conditions, as well as in determining the productivity of machines in real working situation, being these aspects of fundamental importance to subsidize the planning of extraction operations. From this hypothesis, the present study aimed to analyze the operating cycle and productivity of the forest tractor skidder in logging on slopes.

\section{MATERIAL E METHODS}

\section{Caracteristics of the study area}

The survey was conducted in forest plantation of Pinus taeda with 15 years of age, $3 \times 2 \mathrm{~m}$ spacing, clear cut, in a pulp company located in Guarapuava, Midwest region of Paraná State, Brazil. The individual average volume (IAV) [VMI in portuguese] of population was $0.302 \mathrm{~m}^{3}$ and the goal of planting was to generate wood for pulp and sawmill.

According to Köppen classification, the climatic characteristics of the region are considered subtropical $\mathrm{Cfb}$, with regular and well distributed rainfall throughout the year, mild summers and cold winter, with presence of frosts, no precipitation occurring during the data collection period. The predominant soil in the region is Latosol.

\section{Caracteristics of evaluated machine}

The timber harvesting system was the entire tree (full tree). The cutting operation was performed by a feller buncher and the wood extraction, performed in a mechanized way using the forest tractor skidder (Figure 1 ), while the processing of the wood at the roadside was performed by a harvester.

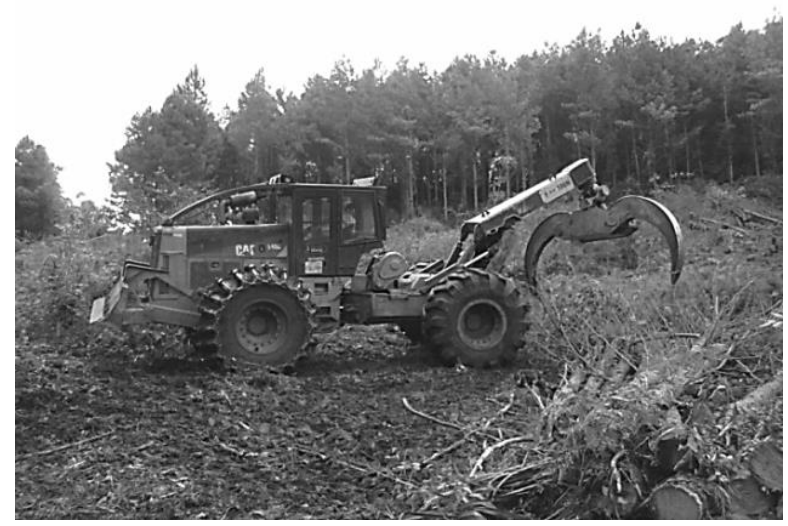

Figura 1. Skidder utilizado no estudo.

Figure 1. Skidder used in the study. 
The machine studied is a Caterpillar Skidder 525C, with nominal power of $152 \mathrm{hp}(113,3 \mathrm{Kw})$, engine CAT 3304 DIT, 13 ton of operating weight, grapple with $1.50 \mathrm{~m}^{2}$ opening area and 13,522 productive machine hours at the beginning of the study.

\section{Technical analysis}

Seeking to analyze only the slope as the study variable, other variables, which could infer the extraction operation, were kept constant, changing only the inclination of the land. Thus, the extraction was studied following methodology used by Simões and Fenner (2010), under homogeneous conditions of extraction, work shift, type of soil, forest, climate, location, and machine operator, that is, varying only the declivity of the slope. The average number of trees swept away by operating cycle was 5.56 , with deviation of 2.45 individuals, depending on the normal work situation.

For technical analysis, it was used a time and motion study, which allowed the analysis of productivity, utilization rate and the average effective time of the operating cycle of skidder, operating at different inclinations of the ground. In the study, it was used the method of continuous-time timing proposed by Barnes (1968), featured for the measurement of the split time of each element without pause with centesimal timer and special field forms.

The operating cycle of the skidder was subdivided in the following partial activities submitted and listed in Table 1, respecting the fact that the termination of a partial activity corresponds exactly to the beginning of the following partial activity.

Tabela 1. Atividades parciais do ciclo operacional do skidder.

Table 1. Partial activities of skidder's operational cycle.

\begin{tabular}{ccl}
\hline Acronym & Partial activity & \multicolumn{1}{c}{ Partial activity description } \\
\hline DV & Empty displacement & $\begin{array}{l}\text { Starts with the movement of the machine of the yard into the plot, } \\
\text { including later maneuver and stopping of the machine before } \\
\text { activating the grapple }\end{array}$ \\
\hline BC & Search and Load & $\begin{array}{l}\text { Starts with the handling and firing of the grapple to capture beam of } \\
\text { trees and ends with the full load to be dragged. }\end{array}$ \\
\hline DC & Loaded Offset & $\begin{array}{l}\text { Starts from the moving of the machine from the interior of the field to } \\
\text { the yard with the tree beams (full load) being dragged, and ends with } \\
\text { the stopping of the machine for the next partial activity. }\end{array}$ \\
\hline DG & $\begin{array}{l}\text { It begins with the machine making movements with its grapple, } \\
\text { opening it and depositing the beam of trees in the yard and ends with } \\
\text { the deposit of the last tree/beam in the yard }\end{array}$ \\
\hline WE & $\begin{array}{l}\text { Starts with a movement soon after the deposit of the beams at the } \\
\text { wood yard, where the machine arranges the wooden beam dragged } \\
\text { using the grapple or the spear and ends with the machine positioned } \\
\text { to enter the site again }\end{array}$ \\
\hline
\end{tabular}

\section{Data collection}

Initially, a pilot study was carried out in order to define the minimum number of observations of the machine operating cycle, providing a maximum sampling error of $10 \%$, according to the methodology used by Conaw (1977), Fiedler et al. (2008), e Pereira et al. (2015).

After defining the minimum size of the sample, it was selected the plots with similar dimensions and the following characteristics: $800 \mathrm{~m}$ in length and $300 \mathrm{~m}$ in width, resulting in a medium drag distance of 150 meters and sloping drag direction. Slope classes are presented in table 2.

Tabela 2. Classes de inclinação.

Table 2. Slope classes.

\begin{tabular}{cc}
\hline Slope classes & Inclination degrees \\
\hline I - Plain to moderate & $0^{\circ}$ a $15^{\circ}$ \\
II - Steep & $16^{\circ}$ a $26^{\circ}$ \\
III - Very Steep & $\Rightarrow>26,1^{\circ}$ \\
\hline
\end{tabular}

This classification has been adapted on the basis of the classification of the Forestry Commission UK (1996) $\left(\right.$ Plain $=0^{\circ}-6^{\circ}$, Soft $=6.1^{\circ}-11^{\circ}$, moderate $=11.1^{\circ}-18^{\circ}$, Steep $=18.1^{\circ}-27^{\circ}$, too steep $=>27.1^{\circ}$ ) and was 
chosen because of the characteristics of the planting fields provided for the completion of data collection which presented similar ramps to such classification.

\section{Average effective time}

For the calculation of the effective time, the formula proposed by Miyajima et al. (2016) was used, in which the average time was obtained by dividing the sum of the effective operating cycles times by the number of cycles (Equation 1):

$$
\mathrm{TEM}=\frac{\sum \mathrm{HE}}{\mathrm{n}}
$$

In which: TEM: effective medium time (minutes); $\sum$ HE: sum of the effective working time (minutes); n: number of operating cycles.

\section{Productivity}

Productivity of machine is calculated in cubic meters of wood dragged per hour of actual work from the following formula (Equation 2):

$$
\mathrm{PR}=\frac{\mathrm{N} x \mathrm{VMI}}{\mathrm{HE}}
$$

In which: PR: productivity $\left(\mathrm{m}^{3} \mathrm{he}^{-1}\right) ; \mathrm{N}$ : number of trees swept away; VMI: individual average volume $\left(\mathrm{m}^{3}\right)$; and HE: effective working time (hours).

\section{Statistical analysis}

The productivity and the effective average time of partial and total cycle activities were submitted initially to the Bartlett test to check whether the treatments were of homogeneous variation. However, when this indicated heterogeneous variance in at least one of the treatments, the data were transformed from the methodology of Box and Cox (1964) to stabilize the existing variability and to normalize the residues. After homogenization, was proceeded entirely with the variance analysis (ANOVA) following the completely randomized design to identify possible differences of productivity and average effective time of the activities between the different classrooms of inclination. When this indicated significance, the averages were compared with the Tukey test at 5\% significance. To perform the analyses, the software R (R CORE TEAM, 2017) was used, and to determine the best value of " $\lambda$ " to be used in the transformation, the "MASS" package was utilized (VENABLES; RIPLAY, 2002).

\section{RESULTS}

\section{Average effetive time}

A total of 126 operational cycles were collected for each forest drag slope class performed by skidder, value higher than the minimum required of 101 cycles for a maximum sampling error of $10 \%$. The average values referred to the time (in seconds) of each activity in the composition of the wood extraction cycle using the skidder for each slope class are shown in Table 3.

Tabela 3. Tempo efetivo médio (em segundos) das atividades que compõem o ciclo operacional do skidder. Table 3. Mean time of the activities that compose the skidder's operational cycle.

\begin{tabular}{ccccccc}
\hline Inclination Class & $\mathbf{D V}$ & $\mathbf{B C}$ & $\mathbf{D C}$ & $\mathbf{D G}$ & $\mathbf{O E}$ & Total Cycle \\
\hline I & $34,01 \mathrm{a}$ & $11,47 \mathrm{a}$ & $29,31 \mathrm{~b}$ & $6,79 \mathrm{ab}$ & $44,10^{\mathrm{ns}}$ & $113,09 \mathrm{a}$ \\
II & $26,30 \mathrm{a}$ & $8,36 \mathrm{a}$ & $19,79 \mathrm{a}$ & $5,45 \mathrm{a}$ & $51,68^{\mathrm{ns}}$ & $108,45 \mathrm{a}$ \\
III & $123,39 \mathrm{~b}$ & $29,30 \mathrm{~b}$ & $79,04 \mathrm{c}$ & $7,96 \mathrm{~b}$ & $43,00^{\mathrm{ns}}$ & $267,74 \mathrm{~b}$ \\
\hline $\mathbf{K}$ & $0,092^{*}$ & $2,125^{*}$ & $2,670^{*}$ & $2,351^{*}$ & $5,312^{*}$ & $1,334^{*}$ \\
$\mathbf{F}$ & $46,15^{*}$ & $17,49^{*}$ & $56,22^{*}$ & $5,58^{*}$ & $1,65^{\mathrm{ns}}$ & $49,66^{*}$ \\
\hline
\end{tabular}

DV: Empty displacement; BC: Search and Load; DC: Loaded Offset; DG: Offloading; OE: Wood-yard organization.

Medium followed by the same letters in the columns do not differ statistically between themselves by Tukey test at $5 \%$ level ( $\left.\mathrm{p}_{\text {value }}>0,05\right)$; $\mathrm{K}$ : Calculated Bartlett test value; F: Calculated Fischer test value; *: significant calculated value at $5 \%$ level $\left(\mathrm{p}_{\text {value }} \leq 0,05\right)$; and ${ }^{\text {ns: }}$ Calculated value is not significant at $5 \%$ level $\left(\mathrm{p}_{\text {value }}>0,05\right)$.

As it can be observed, the inclination class II was the one that consumed less time, showing even statistical difference when compared to the slope class III. Among the partial elements of the skidder operational cycle, the empty displacement element was the one that occupied the highest percentage of the operational cycle, followed by the loaded displacement and organization of the yard. 


\section{Productivity}

The values of skidder's productivity per hour of work for each slope class studied are presented in Figure 2.As it can be observed, slope class II provided the skidder the highest productivity, with a gain of $44.9 \%$ in relation to slope class III.

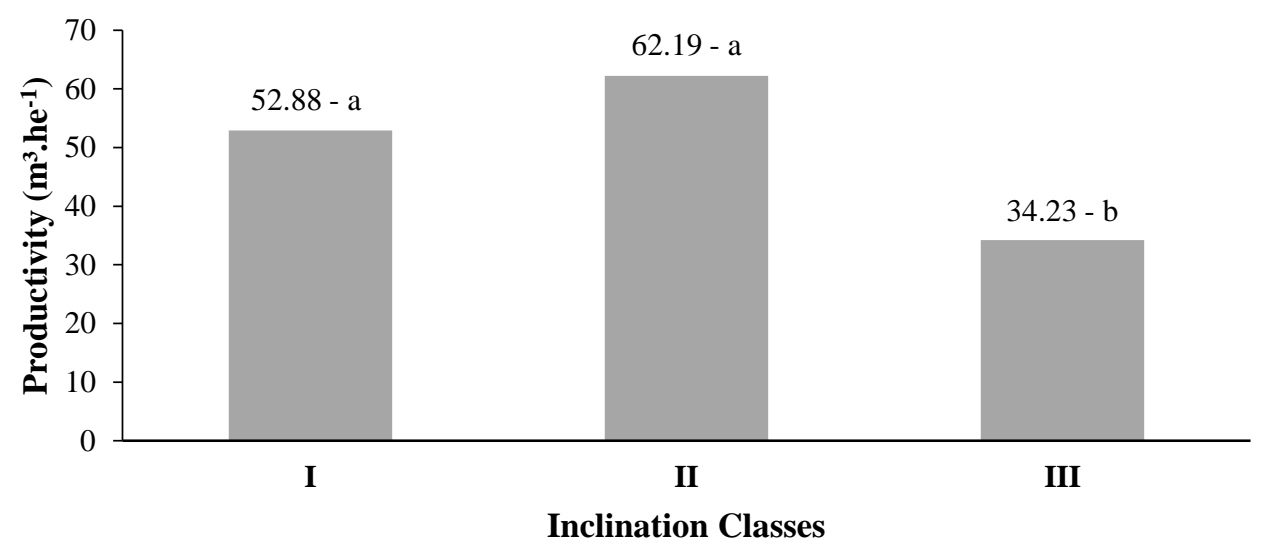

Averages followed by the same letters do not differ statistically between themselves by Tukey test at 5\% level (p > 0,05).

Figura 2. Produtividade média $\left(\mathrm{m}^{3}\right.$ he-1) do skidder nas classes de inclinação estudadas.

Figure 2. Mean productivity $\left(\mathrm{m}^{3} \mathrm{he}^{-1}\right)$ of the skidder in the slope classes studied.

In class I inclination, skidder reached anaverage of 52,88 $\mathrm{m}^{3} \cdot \mathrm{he}^{-1}$, however it presented bigger time of operational cycle in relation to inclination II. The class inclination III was the one which presented the lesser productivity and larger operational cycle time, characterizing as as the class with greater degree of operation difficulty.

\section{DISCUSSION}

\section{Average effective time}

The activities of empty displacement and search and load had presented significant difference in relation to the classroom of inclination III, considering that the biggest inclination of the land affected the operation. In addition to requiring more of the machine in regard to power, the operator had to carry out the activity carefully at the time of loading to avoid possible operational accidents.

The result obtained for the offset to the slope class III proved itself to be approximately $70 \%$ higher than the results of other classes due to a choice of operator, who chose to perform a path that skirted the trees, consuming a larger amount of time in operation because of the terrain inclination.

In the displacement loaded activity, it was observed that the smallest and largest average time were found in classes II and III, respectively. This result is explained by the variation of the inclination between the classes studied. At the time of the operation, on slope class III, the operator of the machine could have made use more frequently of the brakes to avoid the skidding of the machine depending on the inclination of the ground, which could lead to accidents.

Differently from what was observed by Fiedler et al. (2008) and Pereira et al. (2015), the partial element of the empty displacement operating cycle obtained more time spent when compared to the full displacement. This behavior is showed up to be somewhat controversial, although it is justified by the specific feature of the operation, in which the machine performed the drag with the trees in the direction of slope.

Regarding the partial organization of the wood-yard, it was observed that, the less time was spent in the highest difficulty degree of the operation. However, this partial element was characterized by being independent of the slope of the terrain. It appears, therefore, that the operator could be aware of the need to optimize your time in this element of the operating cycle, since the other elements demanded longer time due to the degree of inclination in this class. Thus, it is shown that the time and motion study can provide the identification of need for optimization of the cycle as a whole from training techniques and control.

The search activities and loading and unloading of this research consumed less time of the operating cycle time. According to Sandhu (2008) and Lopes et al. (2017), skidder occupies the longer in active form, i.e.

FLORESTA, Curitiba, PR, v. 49, n. 1, p. 041-048, jan/mar. 2019

Diniz. C.C.C. et.al.

ISSN eletrônico 1982-4688 
performing the operations of empty and loaded displacement, and therefore consuming less proportional cycle time in loading and unloading, corroborating the results of this research.

Considering the average time of all operational activities jointly the inclination classes I and II consumed less time than the inclination class III. The fact that there is no statistical difference between the inclination classes I and II occurred due to the overlapping of the standard deviation, in which the lower limit of a class crosses paths with the top of another $\left(57,88 \mathrm{~m} 3 \mathrm{he}^{-1}\right.$ for the inclination I and $57,19 \mathrm{~m} 3 \mathrm{he}^{-1}$ for class II).

\section{Productivity}

The productivity per effective hour of work of the three inclination classes presented homogeneous variance in the original scale at $5 \%$ of significance. When analyzing the productivity of skidder, it was possible to verify a significant difference $(\mathrm{p}<0.05)$ between the three classes. The biggest average values of this factor were found in classes I and II, with 52,58 e $62,19 \mathrm{~m}^{3} \mathrm{he}^{-1}$, respectively, both statistically superior to the productivity of inclination class III. This behavior was evidenced by Alves et al. (2014), when a skidder was examined in three classes of inclination and a $19 \%$ of reduction in the productivity of the machine on the ground with the greatest slope was obtained.

The values obtained in this study were higher than those found by Lopes and Diniz (2015), which found the average productivity of skidder of $17.56 \mathrm{~m}^{3} \mathrm{he}^{-1}$ and $11,92 \mathrm{~m}^{3} \mathrm{he}^{-1}$ cable in inclination classes I and II, respectively, when examining the operational cycle times and the productivity in logging on slopes in plantations of Pinus taeda at 39 years. The data was also higher than the values of Fiedler et al. (2008), which achieved a productivity of $42,3 \mathrm{~m}^{3} \mathrm{he}^{-1}$ for an average drag distance of 230 meters when studying a grapple skidder on the logging of eucalyptus. From these comparisons, it is evident that the inclination class obtained the lower productivity in studies, although there are differences in productivity due to the specifications of the machines, working conditions and average extraction distances different from the ones in this study.

Despite inclination classes I and II are statistically the equivalent, there was reduction in the machine productivity in inclination class I. This occured due to some class I beam which had less tree quantity than some beams in class II, once the feller buncher responsible to beam confection let them only with $70 \%$ of machine capacity. This shows one more time that despite the existance of such small differences in padronization of the influential variables, they were not sufficiently influent to statistically modify the values obtained in classes I and II. This way, the operator performed a maneuver of grabbing more trees from other wood beam after catching the smaller one, increasing operational cycle time and making class I productivity be smaller than class II.

When analyzing the extraction of eucalyptus wood with a track-skidder in mountainous regions, Birro et al. (2002) concluded that productivity was higher in the lower bands of terrain slope. This corroborates the results gotten in the present work. In comparison with the harvester, Leite et al. (2014b) found significant influence of the variable of inclination in the harvest of eucalyptus, where the income tends to be bigger with the reduction of the land inclination. One perceives, again, that the inclination of the land influences in the productivity of forest machines to the measure that the inclination increases.

Alves et al. (2014) obtained similar results to the behavior obtained in the present study, showing that, with the increase in the degree of inclination, productivity tends to decrease. Leite et al. (2014a), while studying the wood extraction performance with forwarder, and Oliveira Junior et al. (2009), evaluating the productivity of feller-buncher in eucalyptus populations, found a decrease in productivity with the increase of the terrain slope for both machines.

\section{CONCLUSIONS}

- The empty and loaded displacements presented greater time consumption in the operation, thus favoring the low productivity of skidder in very steep slopes.

- Productivity was negatively affected from $26.1^{\circ}$ of inclination. Therefore, it is necessary to consider the implementation of the drag until this inclination. 


\section{REFERENCIAS}

ALVES, G. C.; SCHELBAUER, A. A.; SANTOS, A. da S.; ROBERT, R. C. G. Desempenho do skidder em três condições de relevo na extração de madeira. Enciclopédia Biosfera, v. 10, n. 19, p. 732 - 742, 2014.

ARCE, J. E.; MACDONAGH, P.; FRIEDL, R. A. Geração de padrões ótimos de corte através de algoritmos de traçamento aplicados a fustes individuais. Revista Árvore, v. 28, n. 2, p. 207 - 217, mar./abr. 2004.

BARNES, R. M. Motion and time study: design and measurement of work. New York: Jonh Willey \& Sons, 6 ed. 1968,799 p.

BIRRO, M. H. B.; MACHADO, C. C.; SOUZA, A. P. de; MINETTI, L. J. Avaliação técnica e econômica da extração de madeira de eucalipto com "Track-Skidder" em região montanhosa. Revista Árvore, Viçosa - MG, v. 26, n. 5, p. 525 - 532, set./out. 2002.

BOX, G. E. P.; COX, D. R. An analysis of transformations. Journal of the Royal Society, v. 26, n. 2, p. 211 $252,1964$.

CONAW, P. L. Estatística. São Paulo: Edgard Blucher, 1977, 264 p.

FIEDLER, N. C., CARMO, F. C. de A., MINETTE, L. J., SOUZA, A. P. de. Operational analysis of mechanical cut-length forest harvesting system. Revista Árvore, vol.41 n³ Viçosa, 2017.

FIEDLER, N. C.; ROCHA, E. B.; LOPES, E. S. Análise da produtividade de um sistema de colheita de árvores inteiras no Norte do Estado de Goiás. Floresta. v. 38, n. 4, p. 577 - 586, out./dez. 2008.

FORESTRY COMMISSION UK. 1996. Terrain Classification. Disponível em: <http://www.biomassenergycentre.org.uk>. Acesso em: 01/03/2017.

LEITE, E. S.; FERNANDES, H. C.; MINETTE, L. J.; SOUZA, A. P.; LEITE, H. G.; GUEDES, I. L. Modelagem do desempenho da extração de madeira pelo "forwarder". Revista Árvore, Viçosa - MG, v. 38, n. 5, p. 879 - 887, set./out. 2014a.

LEITE, E. S.; MINETTE, L. J.; FERNANDES, H. C.; SOUZA, A. P.; AMARAL, E. J.; LACERDA, E. G. Desempenho do harvester na colheita de eucalipto em diferentes espaçamentos e declividades. Revista Árvore, Viçosa - MG, v. 38, n. 1, p. 1 - 7, jan./fev. 2014b.

LOPES, E. S.; MISSEL, J. W. P.; DIAS, A. N.; FIEDLER, N. C. Avaliação técnica do trator florestal arrastador "skidder" com diferentes tipos de rodados na extração de madeira em povoamentos de Pinus. Revista Árvore, v. 31, n. 6, p. 1053 - 1061, nov./dez. 2007.

LOPES, E. S.; DINIZ, C. C. Produtividade do trator florestal chocker skidder na extração de madeira em terrenos declivosos. Floresta, v. 45, n. 3, p. 625 - 634, jul./set. 2015.

LOPES, E.S.; OLIVEIRA, D.; RODRIGUES, C. K.; DRINKO, C. H. Variables influencing working time and skidder productivity in wood extraction. Nativa, Sinop, v.5, n.4, p.298-302, jul./ago. 2017.

MACHADO, C. C. Colheita florestal. Viçosa: Editora UFV, 3 ed. 2014, 543p.

MACHADO, C.C., SILVA, E.N., PEREIRA, R.S. O setor florestal brasileiro. In: Machado CC. Colheita florestal. $2^{\mathrm{a}}$ ed. Viçosa, MG: p.15-42. 2008.

MACHADO, C. C.; LOPES, E. da S. Análise da influência do comprimento de toras de eucalipto na produtividade e custo da colheita e transporte florestal. CERNE, v. 6, n. 2, p. 124 - 129, 2000.

MIYAJIMA, R. H.; TONIN, R. P.; PASSOS, J. R. de S.; FENNER, P. T. A Influência da declividade do terreno e do tempo de experiência dos operadores no rendimento do feller buncher. Scientia Forestalis, v. 44, n. 10, p. 443 - 451, jun. 2016.

NASCIMENTO, A. C.; LEITE, Â. M. P.; SOARES, T. S.; FREITAS, L. C. Avaliação técnica e econômica da colheita florestal com Feller-Buncher. CERNE, v. 17, n. 1, p. 9 - 15, mar. 2011.

OLIVEIRA JÚNIOR, E. D. de; SEIXAS, F.; BATISTA, J. L. F. Produtividade de feller-buncher em povoamento de eucalipto em relevo acidentado. Floresta, Curitiba, v. 39, n. 4, p. 905 - 912, out./dez. 2009.

FLORESTA, Curitiba, PR, v. 49, n. 1, p. 041-048, jan/mar. 2019

Diniz. C.C.C. et.al.

ISSN eletrônico 1982-4688

DOI: $10.5380 /$ rf.v49i1.55744 
PEREIRA, A. L. N.; LOPES, E. da S.; DIAS, A. N. Análise técnica e de custo do feller buncher e skidder na colheita de madeira em diferentes produtividades do povoamento. Ciência Florestal, v. 25, n. 4, p. 981 - 989 , out./dez. 2015.

R CORE TEAM. 2017. R: A language and environment for statistical computing. R Foundation for Statistical Computing, Vienna, Austria. Disponível em: <https://www.R-project.org/>. Acesso em: 24/05/2017.

SEIXAS, F. Extração florestal. In: MACHADO, C. C. Colheita florestal. Viçosa: UFV, 2 ed. 2008, 501p.

SIMÕES D, FENNER PT. Influência do relevo na produtividade e custos do harvester. Scientia Forestalis, 2010, 38(85): 107-114.

VENABLES, W. N.; RIPLAY, B. D. Modern Applied Statistics with S. New York: Springer, 4 ed. 2002,495 p. Disponível em: <http://www.stats.ox.ac.uk/pub/MASS4/>. Acesso em: 24/05/2017. 